\title{
選択停車を利用した運転再開直後の運転整理案の自動生成
}

$\begin{array}{llllll}\text { 学生員楊 } & \text { 中 平 } & \text { (東京大学) } \\ \text { 正員古 関 } & \text { 隆 } & \text { 章 } & \text { (東京大学) } \\ \text { 正 員 兽 根 } & \text { 悟 } & \text { (工学院大学) }\end{array}$

Automatic Generation of Rescheduling Plan Immediately after Resumption of Train Operation Using Selective Stops Schedule Pattern

Zhongping Yang, student member, Takafumi Koseki, member (The University of Tokyo), Satoru Sone (Kogakuin University)

It is an important factor for railway services to take proper train rescheduling under disrupted conditions. This paper discusses the rescheduling problem in the case of resumption of train operation, in which the train operation has been temporarily suspended by an accident. The authors propose a novel rescheduling method using selective stops schedule pattern. The proposed rescheduling problem has been formulated as a nonlinear optimization problem, and it has been solved by the simulated annealing method. Finally, the proposed methods are applied to a typical commuter line, and the efficiency of these methods has been verified through simulations.

キーワード：運転整理, 選択停車, 焼きなまし法, IPASS

1. はじめに

列車運行に扔いては、人身事故、車両故障、覀天候など の運転支障による運行乱机が発生すると、乗客に対する サービス品質が急速に低隇してしまう。従って、如何にり アルタイムで運転整理を行うことにより、ダイヤ乱れによ る黒影響を最小限に抑えることができるかは重要な課題で ある。

しかし、高度な計算機技術を擭する今日でも、運転整理 案を定量的に評価する方法がなく、計算機側から運転整理 案に対する評価量を提示できないため、運転整理案の良し 悪しの判断、運転整理案の作成は完全に運転指令員の経験 と勘に任せられているのが現状である。現有の人手に強く 依存した形態から、計算機を主体とした進め方に移行する ために、計算機による運転整理案に対する評価量を提示し、 運転整理案を自動生成できるようなシステムを鉄道事業者 は強く求めている。

現状の蓮転整理の問題点を踏まえ、本稿では、車両故障、 人身事故などに起因する全線あるいは路線の一部が一時運 転サービスが中止した場合の運転再開直後の運転整理を検 討対象とし、乗客にリアルタイム個別案内可能な情報シス テムを導入する前提で、運転整理案の定量的評価法を示し、
速達性と特定の列車への過度な混雑の緩和に寄与できる選 択停車型ダイヤパターンを利用した連転整理案の自動生成 法を提案する。そして、提案手法の有効性をシミュレーショ ンで検証する。

\section{2. 検討对象とする運転整理問題}

列車運行の乱れには小規模なものから大規模なものま で考えられる。発車前の駆け込み乗車や雨の日など乗降に 時間がかかることにより、列車遲延が生じた小規模な運行 乱れについて、現状では遮れが生じた列車の先行列車の出 発時間を謂整する手法、いわゆる列車の間隔制御で、列車 遅延が発散的に增大する問題点が解消されている。一方、大 規模な運行乱れについては、野球終了時のような大イベン トなどによる乗客の增加や大雪による影響など事前に予湘 できる場合は、大規模な運行乱机を避けるように、予め複 数の運行パターンを用意して対応している。また長時間不 通になっている区間がある場合は、運転指令員が考える時 間があるため、適切な運転整理案を作成して対応できる。

本研究では、事故や故障などで 10 分一 30 分程度不通に なることが一番多いから、このような予測できない即時性 を要求される事故路線の運転再開值後の運転整理問題を模 討対象とする。鉄道における運転整理問題は制約要因が多 
く、しかも路線每に事情が違うといった性格を持つため、本 稿は研究の第一ステップとして乗務員運用および車両運用 の制限を考慮しないこととする。また、運転中止時間が長く なると、待ち客に対する駅容量も考虑しなければならない が、本研究は待ち客数が駅容量より少ない運転整理問題を検 討対象とする。

事故や故障が起きると、一時運転サービスが中止されたた め、運転再開直後の際には事故路線の各駅に大量な乗客が溜 まってしまう。現状では、運転再開直後の運行においては、 急行列車から普通列車への变更といった列車種別の格下げ を事業者に容諗しているが、その逆に普通列車から急行列車 への変更といった列車種別の格上げが喼められていない。そ の理由は現有の情報提供システム環境にある。つまり、現有 の情報提供システム環境では、乗客に個別誘導案内できない ため、乗客への案内が容易で誤乗トラブルがないように、運 転再開直後何本かの列車をすべて各駅停車にする手法がよ く用いられることになる。しかし、この手法では駅停車によ る損失時間が大きく、また運転再開直後の最初の列車に乗客 が集中するため、特定の列車への過度な混雑を招く欠点が指 摘さ机る。

本研究では、図1に示すように、事故による運転再開時に 在線した列車を含めた数本の列車を対象列車群と定義する。 対象列車群の本数は運転整理案作成者側が運転再開時点の 乗客需要によって決める。結局、運転再開直後の運転整理案 の作成は対象列車群の運行パターンを決めることになる。本 研究では、事故地点より後の駅間にいる在線列車に関しては 次の駅まで進行させ、車内の全ての乗客を降ろした後にその 列車を新しい列車として定義する。一方、事故地点より先方 にいる列車は基本タイヤ通りに終点まで進行することとす る。

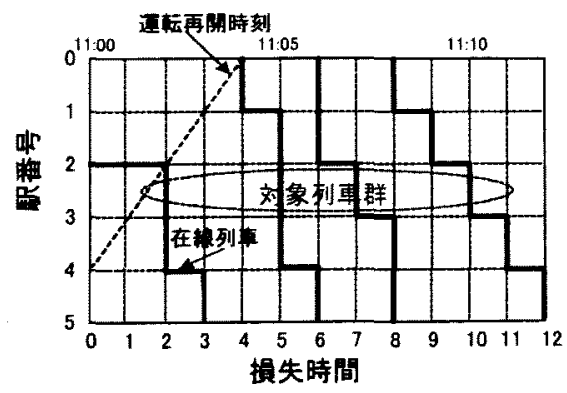

図 1 対象列車群

Fig.1. An objective train group

\section{3. 選択停車を利用した運転整理案の自動生成法の 提案}

$<3 \cdot 1>$ 公共交通利用支援システム

近年、公共交通システムにおける画期的なサービス改善が 期待できる非接触 IC カードシステムの開発が注目を浴びて いる。現在の実用化あるいは研究開発中の非接触 IC カード システムによるサービス改善は主に自動運賃徵収であるが、 文献 (1)で近い将来実現されるべき次世代の公共交通利用シ
ステムとしての IPASS (Intelligent Passenger ASsistance System: 公共交通システム利用支援システム)というものが 提案されている。このシステムは、通信および情報表示・入 力受付などの機能を有するカードないし携帯端末を利用す ることによって、

1.ゲートレス運賃徴収

2.リアルタイム個別乗客案内

3. 超高精度乗客需要の自動把握

の 3 機能を実現し、乗客・交通事業者双方にとって便益を与 えようというものである。

このシステムのリアルタイムの個別案内機能により、利用 者の目的地までの誘導や、ダイヤが乱机たときの利用者への 適切な指示を出せるばかりでなく、次に述べる高速で高密度 な運行を目指した複雑な選択停車型ダイヤを組んだ際にも、 適切に利用者に指示が出せる。

く3・2> 選択停車型ダイヤパターンを利用した運転整理 前述の IPASS を鉄道システムに導入することを前提とす れば、現状では容認されていない列車の格上げも実現可能と なる。そこで、本研究では速達性と特定の列車への過度な混 雑の楥和に寄与できる選択停車型ダイヤパターンを利用し た運転再開直後の運転整理を提案する。

図1に示すように、選択停車型ダイヤとは、複数の列車に 異なる停車駅を分担させたダイヤバターンである(2)(3)。こ のダイヤパターンには、列車を高密度で運行できること、列 車の途中の停車時間に上る損失時間が少なく、列車の平均速 度を向上させることが可能のため、速達性も有するといった 特徴を持っている。また、複数の列車に異なる停車駅を分担 させるため、特定の列車への過度な混雑の緩和にも好まし い。一方、選択停車型ダイヤの本質的な問題点としては、列 車の停車駅パターンによって到達不能 ODペアが生じること である(3)。本研究では、对象列車群の最後の1本の列車を 各駅停車することでこの問題を解消する。なお、付録で図 1 のダイヤパターンの書き方を補足説明する。

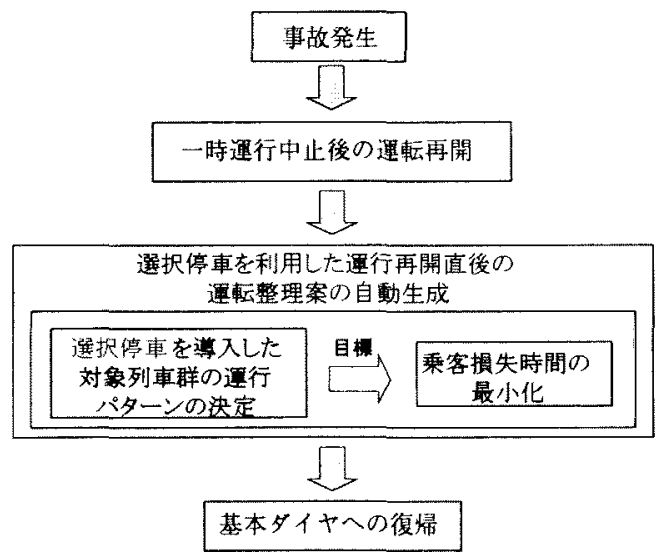

図 2 検討概要

Fig.2. Outline of this research 


\section{$<3 \cdot 3>$ 運転整理案の自動生成}

選択停車型ダイヤパターンを探用した対象列車群の運行 パターンは多数ある。運転再開直後の運転整理案の決定は、 多数の選択可能なパターンの中から予め決められた評価基 準に基づいて、最良な運行パターンを見出すことになる。本 研究では、計算機による運転整理案を自動生成するように、 運転整理案の定量評価方法を定め、最適化手法を用いて運転 整理案の決定を行う。その詳細はそれぞれ次の4、5章に示 す。本稿の検討概要を図 2 に示す。

\section{4. 運転整理案の評価}

本章では運転整理案の乗客からみた評価項目を考慮し、そ の定式化を示す。

\section{$<4 * 1>$ 基本定義}

対象列車群の数および初期位置情報は対象列車群ベクト ルdで次の上うに表す。

$$
d=\left(d_{l}, d_{2}, \ldots, d_{n-1}\right)^{\mathrm{T}}
$$

ここで、nは事故路線の駅数を表す。 $d_{i}$ は運行再開直後に $i$ 駅から出発する列車の数である。一例として、図3のよう な路線では、運行再開直後に対象列車群ベタトルは

$$
d=(3,0,1,0,0,0)^{\mathrm{T}}
$$

となる。

対象列車群の運行パターンは行列

$$
P=\left[\begin{array}{cccc}
p_{00} & p_{01} & \ldots & p_{0 n-1} \\
p_{10} & p_{11} & \ldots & p_{1 n-1} \\
\ldots & \ldots & \ldots & \ldots \\
p_{m-10} & p_{m-11} & \ldots & p_{m-1 n-1}
\end{array}\right]
$$

で表現する。ここで、 $m$ とnはそれぞれ対象列車群の列車数 と駅数を表す。 $p_{i j}$ は 0 か 1 の二值を取る数で、その条件を

$$
p_{i j}= \begin{cases}0 & i \text { 列車が } j \text { 駅に停車しない場合 } \\ 1 & i \text { 列車が } j \text { 駅に停車する場合 }\end{cases}
$$

と定義する。

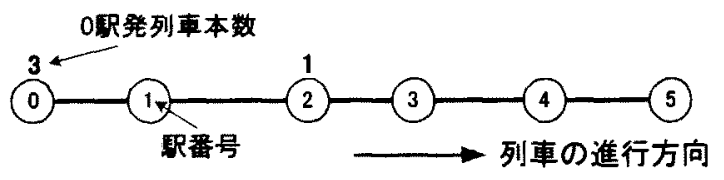

図 3 路線モデル

Fig.3. Line model

\section{$<4 \cdot 2\rangle$ 評価関数}

$\langle 4 \cdot 2 \cdot 1>$ 総乗客損失時間 実際に乗客が出発駅から目 的駅に着くまでかかる乗車時間と出発駅での乗車待ち時間 の和から、乗客が出発駅から無停車で目的駅に行くとした場 合にかかる時間を引いたものをその乗客の損失時間とする。 この総和をある運行パターンPの全乗客損失時間と呼ふ。評 価関数として式で表すと

$$
T_{l o s s}=\sum_{i=1}^{N}\left[\left(t_{i}^{\prime}+t_{i}^{\prime \prime}\right)-t_{i}\right]
$$

となる。ここで、各変数は

$T_{\text {loss }}$ : 運行パターンPの総㝜客損失時間

$t_{i}^{\prime}$ : 乗客 $i$ が出発駅から目的駅に着くまでの乗車時間

$t_{i}^{\prime \prime}:$ 乗客 $i$ の出発駅での乗車待ち時間

$t_{i}:$ 乗客 $i$ が出発駅から無停車で目的駅に行くとした場 合にかかる時間

$N:$ 乗客の総数

として与えられる。 $<4 \cdot 2 \cdot 2>$ 列車の混雑度 各列車・区間毎の混雑度は次の 式で計算することができる。

$$
f_{i j}=\frac{q_{i j}}{C}
$$

ここで

$f_{i j}: i$ 列車 $j$ 区間の混雑度

$q_{i j}: i$ 列車の $j$ 区間における乗車人数

$C$ ：列車定員

特定の列車がひどく混雑していると極端に不利益を被る 乗客が出てくることになるだけでなく、積み残しを生じた り、再び運行乱就をもたらしたりする恐礼もあるので、特定 の列車への過度な混雑を回避すべきである。混雑度の最大值 を用いて、最悪な混雑状況を評価する。

次に、対象列車群の全体の混雑状況の評価としては、塞効 混雑度を用いて評価を行う ${ }^{(8)}$ 。実効混雑度とは、各列車の 混雑度を混雑を体験する乗客数と混雑を体験する時間とで 重みづけして平均したものである。式で表すと

$$
g=\left(\sum_{i=0}^{m-1} \sum_{j=0}^{n-2} f_{i j} \cdot q_{i j} \cdot t_{i j}\right)\left(\sum_{i=0}^{m-1 n-2} \sum_{j=0}^{n} q_{i j} \cdot t_{i j}\right)
$$

となる。但し、

$$
\begin{aligned}
& g: \text { 対象列車群の実効混雑度 } \\
& t_{i j}: i \text { 列車 } j \text { 区間における走行時間 }
\end{aligned}
$$


である。

〈4·3> 列車区間別乗車人員の計箁アルゴリズム

ある対象列車群の運行パターンが与えられた際の評価量 の計算方法について本節で説明する。

$<4 \cdot 3 \cdot 1>$ 乗客需要と乗客乗車行動仮説本研究は地下 鉄や都心対郊外型のような高密度翰送の通勤・通学路線を考 察対象とするため、事故前後で各駅での乗客需要の発生率が 変化せず、予め知られているものとする。再開直後の対象列 車群を利用する乗客需要には

1. 運転再開時点に各駅にたまった乘客需要

2. 運転再開後に発生した乗客需要

がある。

また、乗客の乗車行動は次の仮説に基くとする。

1、最も早く目的駅に到着するように列車を選択する。

2. 目的駅への到着時刻が同じならばなるべく乗換回数 が少ないように列車を選択する。

<4・3・2> 最短乗車パスの探索出発駅から目的駅まで の乗車可能パスは複数存在するのが一般的である。本研究で は対象列車群の運行ダイヤを一つのグラフと見なし、ベルマ ンの最短経路探索アルゴリズム(7)を用いて乗客の最短乗 車パスを探索した。対象列車群の運行ダイヤのグラフモデル は次の通りである。

まず、駅をグラフ $\boldsymbol{G}$ のノードにモデル化すると、事故路 線に駅 $n$ 個があるとすると、グラフ $\boldsymbol{G}$ のノード集合は

$$
S=\left\{S_{1}, S_{2}, \cdots, S_{n}\right\}
$$

となる。次に对象列車群の各列車をグラフ $G$ のラインにモ デル化し、グラフ Gのラインの集合は

$$
L=\{l l, l 2, \cdots \cdot l m\}
$$

となる。そうすると、対象列車群運行ダイヤはグラフ G

$$
\boldsymbol{G}=\{L, S\}
$$

にモデル化される。

さらに、各列車の各駅における着発時刻はノードの属性 データとして与える。すなわち、各ノードSi に対して、Si $\in l_{j}$ のとき、 $a_{i j}\left(S_{i}\right)$ と $d_{l i}\left(S_{i}\right)$ はそれぞれ駅 $S_{i}$ に㧍ける列車 ljの到着時刻と出発時刻を表すことになる。

上述のように対象列車群の運行ダイヤをモデル化すると、 グラフ理論におけるベルマンの最短経路探索アルゴリズム のアークをラインに拡張し、ライン上の各ノードのラベリン ク操作を行うことで、最䂑乗車時間パスの探索ができる。

<4.3.3> 乗客の割付乗客の選択乗車バスに治って列 車への乗客割付を行えば、列車区間別の乗車人員の推定と乗
客の目的地までの乗車損失時間及び列車間混雑率の均一化 の誈価量の計算が可能となる。

\section{5. 最適運行パターンの探索}

長時間不通による各駅にたまった乗客は、運転再開後に自 分の旅行時間の延長を最小限に抑え、できる限り早く目的地 に着きたいという考えを持つ。従って、前節の総乗客損失時 間直目的関数とすることは妥当である。決定変数としての対 象列車群運行パターンは $P$ で、目的関数を数式で表すと

$$
\min _{P} \sum_{i=1}^{N}\left[\left(t_{i}^{\prime}+t_{i}^{\prime \prime}\right)-t_{i}\right]
$$

となる。式中の各記号の意味は式（5）と同じである。

制約条件としては、まず対象列車群の各列車は始発駅と 端末駅に必ず停車するため、

$$
p_{i s_{i}}=1, p_{i n-1}=1 \quad(i=0,1, \ldots, n-1)
$$

となる。ここで、 $s_{i}$ は $i$ 列車の始発駅を表す。対象列車群の 運行パターンが異なれば、前節で述べた運行パターンの評価 量も変わってくる。対象列車群の始発駅と終着駅を除いて総 サービス可能駅数を $x$ 個とすると運行パターンは $2^{x}$ 通り存 在することになる。こ机らのパターンを全て評価し、その中 から最良なものを選占全数探索は最も単純かつ確実なアル ゴリズムである。しかし、この方法は多くの評価量の悪い運 行パターンについてもいちいち調べなけ机ばならず、効率が 悪い。簡単なモデルを解こうとしても、澎大な時間がかか る。そこで、本研究では、適切な運行バターンを効率上く見 つける方法として、焼きなまし法 (Simulated Annealing: SA) （4）（6）を適用した。この方法では、局所解へ陷るのを防ぐ ために、山登り法（Hill-Climbing: HC）に確率的な遙移を導 入している。

本研究では、ある運行パターン Pの近傍の定義は次の通り である。まず、運行パターン行列 P を

$$
\left(p_{00}, p_{01}, \ldots, p_{0 n-1}, p_{10}, p_{l i}, \ldots, p_{m-1 n-1}\right)
$$

のように $(m \times n)$ の長さを持つ0と1のビット列に書き換 える。次に、式（13）の隣合う 3 ビットの部分列をランダム に選び、ヒューリスティッタに決めた確率で、ビット列の順 序逆転か、0を1に、1を0に反転させるように突然変異を 施すによる近傍を用いた。

また、温度 Tの更新は

$$
\text { New Temperature }=\alpha \times \text { Temperature }
$$




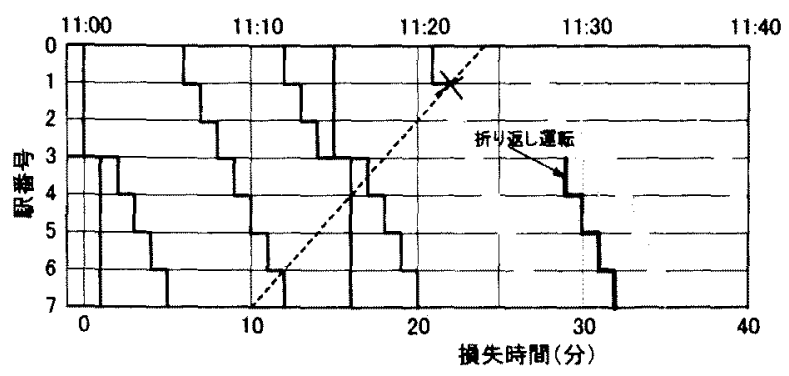

図 4 モデルの運行ダイヤ

Fig.4. Operation diagram of model

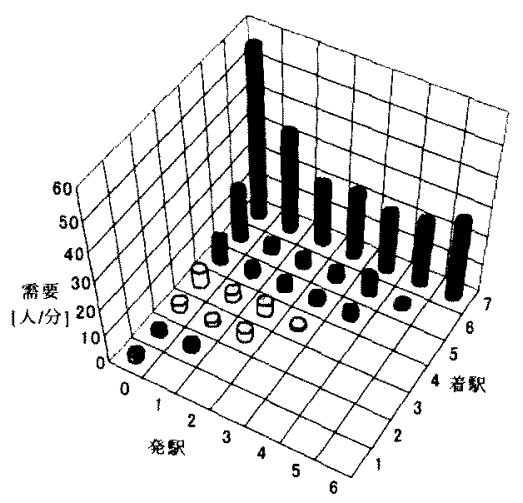

図 5 モデルの萧客需要 (人/分)

Fig.5. Demand of model (person/minute)

によって行う。ここで、Temperature は更新前の温度值、New Temperature 浭新後の温度值、 $\alpha$ は0－19温度勾配である。

6. シミュレーション

本研究で提案した手法の有效性を確かわるた、通勤・通 学輸送を担う典型的な路線としての都心対郊外型路線を用 いてシミュレーションを行った。

$\langle 6 \bullet 1>$ 検証モデル

図 4 は周期 15 分の都心対郊外型路線モデルのダイヤを示 す。この紱急結合型ダイヤでは 1 周期に急行 1 本、各停 2 本 を連行、列車は車両定員 144 人 10 両編成で運行する。また、 列車の駅間走行時間は 2 分と設定した。モデル路線の上り方 向の1分每の乗客需要を図 5 に示す。典型的な都心対郊外型 路線の乗客需要として、図 5 から都心駅 7 に行く乗客需要が 他に比べて圧倒的に多いことが分かる。

想定する運転整理の場面は11:24 分に 1 駅において、0 駅 11:21 発の各停列車が 30 分止まってしまい、30 分後、つま り11:54 分から運行を再開するとした。追い越し、折り返し、 車两格納の可能な駅を 3 駅に設定した。なるべく乗客の損失 を減らすために、運転再開までに運行可能な区間で折り返し 運行を実施させるべきである。本シミュレーションでは、因 4 と図6に示すように、運転再開までに駅 3 と駅 7 の間の乘 客需要を考滤して、列車 2 本が 12 分の間隔で折り返し運転 を行うとした。対象列車群の本数 $m$ は、再開時点に各駅に溜
まった乗客需要による最大断面交通量 $y_{\text {max }}$ と列車定員 $C て ゙$ 次の式で決めることにした。

$$
m=\frac{y_{\max }}{C}
$$

ただし、mは整数でなければならないので、四捨五入で $m$ を 決定する。このモデルタースでは、対象列車群本数は 5 と なった。今回のシミュレーションでは、0駅 11:27、11:36お よび 11:51 発の各停、0 駅 11:30 発の急行列車を運休させる とした。実際、駅停車時間は乗降客数によって变化するもの であり、乗降客数に上る停車時間の変化を提案手法に入れて も同梯の解法が適用できるが、シミュレーションでは簡単の ため駅停車時間を乗客数と関係なしに1 分と仮定した。

\section{$<6 \cdot 2>$ 検証結果と考察}

対象列車群数温度勾配 $\alpha=0.9$, 初期温度 $T_{0}=4000.0$ 、温 度 New Temperatureく1.0を終了条件とした時の SA 法を用い て最適運行パターンの探索を行った。図 6 はSA 法を用いて 得ら九た最適な対象列車群の運行再開直後の運行ダイヤを 示す。対象列車群の各列車は異なる駅間需要を複数の列車で 分担して挪くような形になっていることが分かる。なお、今 回のシミュレーションは Pentium II (450MHz)、RAM 256MB のパソコンを使用し、500 個の初期パターンから最適解の探 索で 2 分 9 秒を要した。問題の準最適解を奏用的時間で算出 できる見通しが得られた。一方、全数探索で行おうとすれ ば、概ね 49 時間 42 分がかかることとなる。

一方、現状ではよく使わ机ている全各駅停車による運転整 理案を図 7 に示す。また、現状では普通列車から急行列車へ の変更といった列車種別の格上げを事業者に容認していな いことから、図 8 は列車種別の格上げをしない場合の楥急結 合型の運転整理案を示す。

表 1 運転整理法別の評価量

Table 1. Evaluated values obatained by respective rescheduling methods

\begin{tabular}{|c||c|c|c|}
\hline 運転整理方式 & 損失時間 (分) & $\begin{array}{c}\text { 最大混雑度 } \\
(\%)\end{array}$ & $\begin{array}{c}\text { 実効混雑度 } \\
(\%)\end{array}$ \\
\hline \hline 全各停 & 174535 & 265 & 201 \\
\hline 楥急結合 & 160473 & 265 & 170 \\
\hline 提案手法 & 158713 & 195 & 146 \\
\hline
\end{tabular}

表 1 は提案手法による運転整理案と、現状の運転整理法と しての全各停と楥急結合型方式による評洒量を示す。提案手 法による乗客の損失時間の削減ができたことがわかった。そ れから、列車混雑状況の観点から考察してみる。全各停と楥 急結合の最大混雑度が $265 \%$ (運転再開後、駅 $11: 54$ 分発の 列車）になったのに対して、提案手法の最大混雑度が $195 \%$ まで低隇できた。表1の計算值は列車容量を考慮せずに算出 した結果である。しかし、実際に列車容量の制限があるた め、列車混雑度が $250 \%$ に達すると、「電車が摇れるたびに 


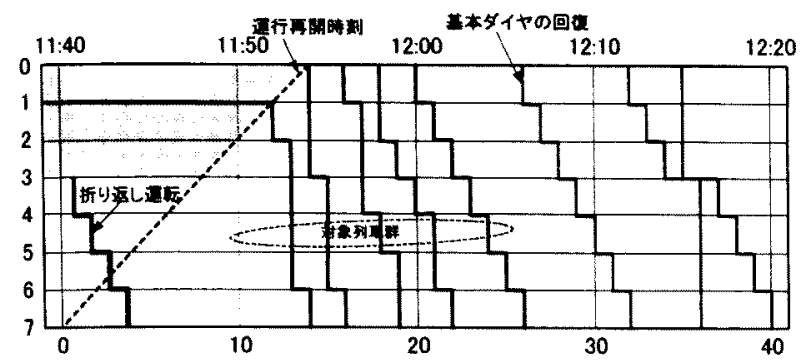

図 6 提案手法による運転整理案

Fig.6. Rescheduled plan by the proposed method

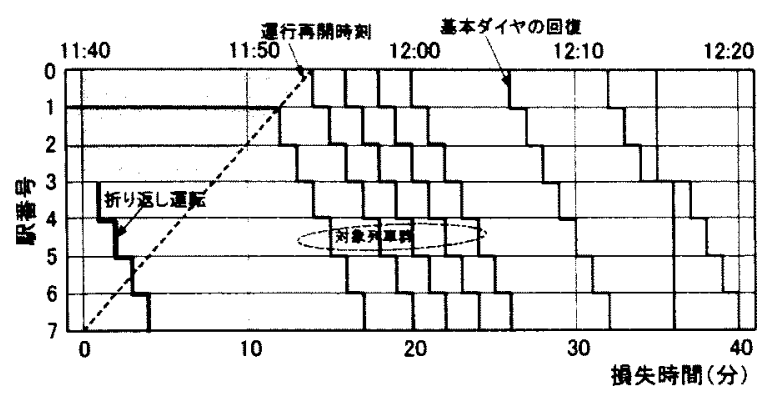

図 7 全各停による運転整理

Fig.7. Rescheduling plan with all local method

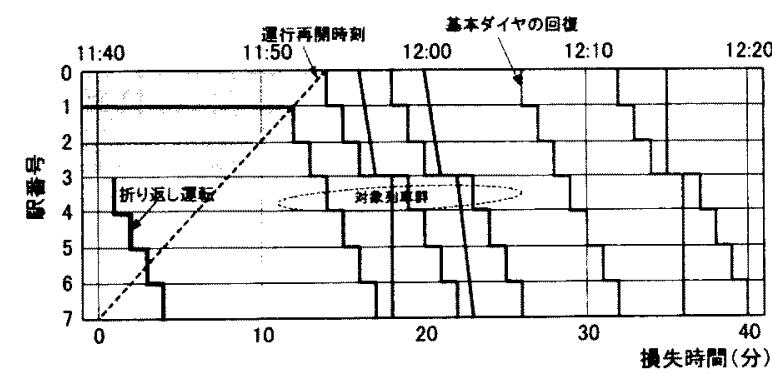

図 8 緩急結合による運転整理

Fig.8. Rescheduling plan with combined fast and slow trains

体がななめになって、身動きができず、手も動かせない」と いう状況になるため、もはやこれ以上乗客が列車に乗り込め ない状況である。混雑度 $250 \%$ を最大許容混雑度と呼ぶこと とする。列車容量以上の乗車要求があった場合には乗客を積 み残してしまう。したがって、提案手法が従来の手法と比べ 特定の列車への過度な混雑の回避ができたことも分かった。 また、対象列車群全体の混雑状況を反映する実効混雑度の観 点からみても提案手法が優れていることも確認できた。

\section{7. おわりに}

本研究では、乗客にリアルタイム個別案内可能なIPASS ような情報システムを導入することを前提に、近将来の運転 整理手法として、選択停車を利用した運転再開直後の運転整
理案の自動生成法を提案した。すなわち、運行再開直後の運 転整理案の評価式を確立し、運転再開後の運転整理案の自動 生成を準最適化問題に帰着させた。

典型的な通勤・通学路線としての都心対郊外型路線モデル についてのシミュレーションを行った結果から、提案手法に よる運転整理案は乗客の損失時間削隇と特定列車への過度 な混雑への回避の両立に寄与しうることを確かめた。

本研究では、大事故を生じた際の単一路線のみを議論の对 象にした。今後は、乗客の迂回ルート使用、他路楾の運転計 画の変更などネットワークにおける運転整理問題を検討し てゆく。

付録：損失時間によるダイヤ表記

列車ダイヤは一般的には時間軸と距離軸(駅が順番に配置 されている)を持つ平面上に表現される。これは、任意の時 刻における列車の位置、追い越しの様子などを把握するには 適切な力法である。

しかし、ダイヤの理論的作成、特に計算機を利用する為に は、簡単且つダイヤの評佂が行い易いダイヤ表現が必要であ る。ダイヤの評価として、最も重要なのは利用者の乗車損失 時間、すなわちある乗客の利用駅間に直行サービスが存在す ると仮定したときの所要時間からの漣九分であるから、駅停 車による損失時間が明確にわかるダイヤ表現が望ましい。こ の停車列車と通過列車の所要時間差の標準的な值としては、 通勤電車・郊外電車では、駅停車による損失時間は駅間の距 離や速度、所要時間には無関係にほほ1分/駅であるから、 ダイヤ案の検討段階では方眼紙を用いて図1のように簡単で 要領よく停車パターン等が議論できる。さらに、停車パター ンが 2 值化できるため、計算機によるダイヤ評価、作成に向 いている。このダイヤ表記法は既に多くの鉄道でダイヤ作成 者の間で利用されており、一部では曽根式ダイヤと呼ばれて いる。

困1に示す損失時間によるダイヤ表記では、駅間所要時間 を直接反映していないため、駅ごとにおける同一時刻を表す 等時線は斜めの線で表すこととなる。一例として、図 1 の斜 めの点線は駅間所要時間が 1 分とした場合の運転再開時刻 11:04を表している。

(平成 13 年 2 月 16 日受付、平成 13 年 10 月 5 日再受付)

文献

（1）高木, 原口, 曾根：「公共交通利用個別支援システム IPASS」, 平成 9 年電気学会交通・電気鉄道研究会資料 TER-97-50, 1997 
(2) S.Sone: "Novel Train Stopping Patterns for HighFrequency, High-Speed Train Scheduling", COMPRAIL'92, pp.107-118, 1992

(3) 金田, 曾根:「高速・高密度運行のための列車配置手法 の検討」, 電気学会・電気鉄道研究会, TER-93-46, 1993

(4) Kirkpatrick, S., Gelatt Jr., C.D. and Vecchi M.P.: "Opti malizaition by Simulated Annealing", Science, Vol.220, pp.671-680, 1993

(5) Richard Bellman and Robert Kalaba: "Dyanamic Programming and Modern Control Theory", Academic Press, 1965

（6）長尾:「最適化アルゴリズム」, 昭晃堂, pp.120-135, 2000

（7）小川, 古関, 曽根:「バイナリダイヤを利用した列車ダ イヤの合理的作成法」, 平成 6 年電気学会全国大会 762 , pp.6-195 6-196,1994

(8) 曽根:「新しい列車ダイヤと運行管理の手法について」, 社会科学論集, No.99-100 合併号, pp.23-24, 埼玉大学 経済学会, 2000

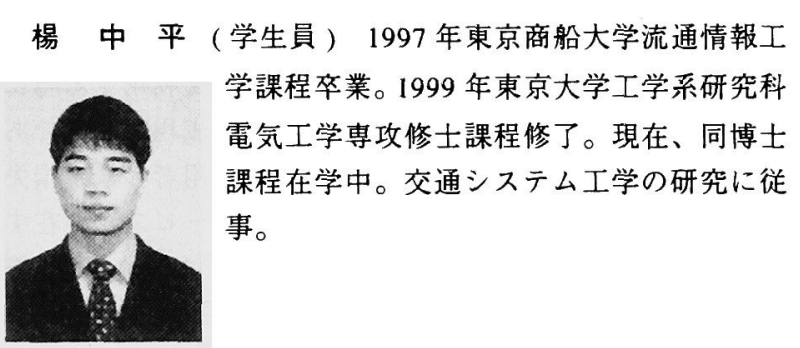

古 関 隆 章 (正員) 1963 年 7 月 29 日生まれ。1992

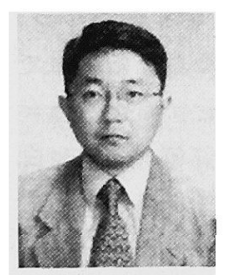
年東京大学大学院工学系研究科電気工学尃 攻博士課程修了。同大学工学部講師、助教 授を経て、現在、同大学工学系研究科電気 工学専攻助教授。工学博士。電気機器制御 の交通・輸送分野への応用の研究に従事。 電気学会、IEEE、VDI 会員。

曾 根 悟 (正員) 1939 年 4 月 23 日生。1 962 年東京 大学工学部電気工学科卒業。1967 年同大学 大学院博士課程修了、工学博士。東京大学 講師、助教授、教授を経て、2000 年 4 月よ り工学院大学教授、現在に至る。専門は交 通システム工学。1982 年論文賞、1996 年 産業応用特別賞学術賞受賞。 